\title{
ALLOWANCES AND THE SEARCH FOR JUSTIFICATION
}

\author{
JESSICA PALMER*
}

This article provides a response to the article in this volume entitled 'What Shall We Do with the Dishonest Fiduciary? The Unpredictability of Allowances for Work and Skill' by Bronwyn Arnold. It begins in Part I with an overview of Arnold's position and moves on to consider the issue of dishonesty in Part II and the notion of unjust enrichment in Part III. Part IV explores two narrower grounds upon which allowances could be justified and concludes that neither dishonesty nor unjust enrichment provides a sound basis for the awarding of an allowance to a breaching fiduciary.

\section{CONTENTS}

I Introduction .21

II Dishonesty .22

III

Unjust Enrichment. .23

\section{INTRODUCTION}

A fiduciary breaches his or her fiduciary duty and is required to account to the principal for profit made as a result of the breach. What effect, if any, should the fiduciary's exertion of skill and effort have on the remedy that the principal receives? Is it appropriate for a fiduciary to be granted an allowance out of the profit? This is a question that has received varying responses from courts that are near impossible to reconcile, and that have significant implications for our understanding of both fiduciary duties and remedies for breach. Bronwyn Arnold is to be congratulated for a thought-provoking article that both

BCom, LLB(Hons) (Auck), LLM (Cantab), LLM (Auck); Associate Professor of the Faculty of Law at the University of Otago, New Zealand. 
highlights how inconsistent and therefore problematic the case law is and advocates for clarity on this issue. ${ }^{1}$

Arnold identifies in the cases what she calls two approaches to determining the availability of allowances: the 'dishonesty approach' whereby an allowance is given to, or withheld from, a breaching fiduciary depending on whether the fiduciary's breach was committed honestly or dishonestly, respectively; and the 'unjust enrichment' approach whereby an allowance is made in instances where the principal could be said to be unjustly enriched by the value of the fiduciary's work and skill applied in making the profit. Having decided that the first approach cannot be explained as a concern for deterrence and thus ultimately amounts to rewarding an honest defendant and punishing a dishonest defendant, Arnold rejects such an approach on the basis that equity is not and should not be concerned with punishment. The unjust enrichment approach is instead preferred because, it is argued, the fiduciary's work in generating the profit has value, which value belongs to the fiduciary, regardless of the fiduciary's motivation for breach.

\section{DISHONESTY}

Although the cases can be grouped into those that refer to dishonesty and those where unjust enrichment is invoked, it is important to note that dishonesty and unjust enrichment do not provide alternative answers to the same question. Where a court makes an allowance so as to prevent the unjust enrichment of the principal, it can be understood as providing a justification for the availability of allowances. On the other hand, refusing or reducing an allowance where the fiduciary has been dishonest or has acted in bad faith does not explain why an allowance would otherwise be given. Dishonesty (or honesty) is being used, not as a justification for allowances, but as a mechanism to control their availability. More is needed to explain the availability of allowances under the dishonesty approach.

A difficult issue not commented upon in the allowance cases is what amounts to dishonesty. What is the relevant standard and how is it to be established in each case? Quite apart from this, dishonesty is a problematic restriction on allowances if what is meant by this is simply that honest fiduciaries acting in good faith should not be punished to the same extent as dishonest fiduciaries

Bronwyn Arnold, 'What Shall We Do with the Dishonest Fiduciary? The Unpredictability of Allowances for Work and Skill' (2016) 2 University of South Australia Student Law Review 1. 
by a full accounting of the profit. A contrast between honestly and dishonestly breaching fiduciaries is irrelevant because liability for breach is strict. Breaching fiduciaries are liable to account, regardless of their motivation to breach. A breaching fiduciary's honesty in so breaching does not justify receipt of an allowance, just as it would not for a party breaching a contract or for a tortious wrongdoer. To reward honesty would undermine the strict nature of the duty.

Even if allowances could be justified for some other reason, the use of dishonesty as a subsequent control factor is inappropriate. Withholding allowances from the dishonest fiduciary would be little more than punishment, which is inconsistent with equity's jurisdiction. As is well known, equity and penalty are strangers. And, as Arnold argues, it is unlikely that the restriction on the availability of allowances has any deterrent effect on breaching fiduciaries such as could provide separate justification. ${ }^{2}$

\section{UNJUST ENRICHMENT}

The unjust enrichment approach also has flaws. If unjust enrichment is taken to mean that part of the substantive private law that concerns restitution for defective transfers, the analysis is strained. Some might suggest that a quantum meruit for the value of services would be an appropriate measure of relief ${ }^{3}$ but a substantive cause of action that justifies this type of relief must be found. What would be the ground for saying that the principal's receipt or retention of a full account of profits is unjust? Was the fiduciary mistaken in applying their skill or effort for the benefit of the principal such that the principal should have to make restitution of the value of that benefit? ${ }^{4}$

This seems a little confused given that the fiduciary was obliged to act for the benefit of the principal, and the principal will have expected the fiduciary to do so. There was a clear basis for the transfer of benefit. The fiduciary was already obliged to confer those services on the principal. The presence of the

Arnold, above n 1, 15.

3 See Anja Kantic, 'Allowances for Breaching Fiduciaries to Ensure that the Principal who Seeks Equity Must Do Equity: Why not Quantum Meruit?' (2016) 2 University of South Australia Student Law Review 26.

4 This could, oddly, explain the relevance of dishonesty to allowances: If the fiduciary dishonestly breaches their duty to the principal, they cannot be said to be mistaken about benefitting the principal with the value of their services because they knew that they were obliged to do so. Yet, to allow the honestly breaching fiduciary to claim mistake undermines the strict nature of fiduciary liability, as discussed earlier. 
obligation negates any unjust factor (or establishes a basis for the transfer if an absence of basis approach is taken to unjust enrichment). ${ }^{5}$

It may be that when courts refer to the function of allowances as preventing the unjust enrichment of the principal, they are not using unjust enrichment in its substantive, technical sense but rather as a label for more popular notions of fairness and just desert. The allowance is made as a deduction of gross profit on the assumption that the fiduciary should be entitled to the worth of their skill and effort. ${ }^{6}$ In many of the allowances cases, references to justice and fairness are not difficult to find. The effect of such statements is really to say that the strict remedy of account of profits is an unjust response to breach of fiduciary duty because it gives the principal more than that to which they should be entitled. However, this sentiment seems to run counter to the nature of the fiduciary obligation and the resulting relief from breach and undermines the very purpose of appointing a fiduciary (or imposing fiduciary obligations). The fiduciary relationship is inherently one where the principals entrust their property or interests to the fiduciary and are assured by the application of fiduciary duties that the fiduciary will exercise judgement over the property or interests loyally for their benefit. The fiduciary's skill and effort must normally be applied for the benefit of the principal by virtue of the fiduciary's obligation of loyalty. Fiduciaries are often appointed specifically for their skill and acumen that the principal can expect will be exercised for their benefit. It is not an automatic right of the fiduciary to any remuneration for such qualities. Indeed, it will be a breach of the fiduciary's duty to be so remunerated without express agreement or authorization. When fiduciaries breach their duty, they are required to hand over to the beneficiary everything derived from that act of disloyalty. While the remedy may seem harsh in the eyes of the fiduciary or a stranger to equity, especially when what was derived was not merely a result of the opportunity arising from their fiduciary position but also of their own skill and effort, it is nevertheless entirely appropriate in order to give effect to the significantly onerous obligation of loyalty.

\section{ALTERNATIVE EXPLANATIONS}

There may, however, be two narrower grounds upon which allowances could be justified. First, as just suggested, an allowance may be authorised by the

5 R Havelock, 'A Taxonomic Approach to Quantum Meruit' (2016) 132 Law Quarterly Review $470,477-8$.

6 See further, M Harding, 'Justifying Fiduciary Allowances' in Tang Hang Wu and Andrew Robertson (eds), The Goals of Private Law (Hart Publishing, Oxford, 2009), 341. 
principal. ${ }^{7}$ Just as the duty can be modified by the parties, so too can the nature or measure of relief. An allowance may then be available if authorised by the principal, whether expressly or impliedly as consistent with the arrangement between the parties. For example, a joint venture agreement may permit one of the parties to a greater share of the profit on account of their particular expertise or the extent of labour exerted and that arrangement may hold even in the event of breach in order to give effect to the parties' intentions. ${ }^{8}$

Secondly, an allowance may be appropriate to reflect that portion of the profit that was caused by the application of a fiduciary's own skill, expertise or time where, and only where, such skill, expertise or time was not subject to the fiduciary duty. So, where a fiduciary is employed for particular expertise or for a particular task, and a subsequent profit can be attributed partly to the breach of their duty and partly to the application of other skills for which they were not appointed or for skills which were applied before they undertook fiduciary obligations, then not all of the profit should be subject to the account. In this sense, the allowance is operating as a type of remoteness rule employed in calculating the profit properly resulting from the breach of fiduciary duty and subject thereby to an account. It would probably be better to abandon the terminology of allowances in this context to avoid any perception that it is some sort of discretionary award distinct from the process of accounting.

The important point about both of these grounds is that they focus on the content of the duty owed by the fiduciary to the principal and, as such, they do not conflict with that duty or with the general principle that a breaching fiduciary must account for profit made in breach of duty.

Arnold has admirably endeavoured to provide an account of allowances that would allow at least one line of the cases to remain standing, but it seems to me that neither dishonesty nor unjust enrichment provides a sound basis for the awarding of an allowance to a breaching fiduciary. For the most part, the approaches taken by the courts to the question of allowances create confusion for the content of the fiduciary duty and the remedy of account of profits. A better analysis is, with respect, still awaited.

Guinness plc v Saunders [1990] 2 AC 663.

8 See alternative approaches on this point in Chirnside v Fay [2007] 1 NZLR 433 (NZSC) and Murad v Al-Saraj [2005] EWCA Civ 959. 